\title{
The Impacts of Medications Misused for Body Weight Gain on Complete Blood Count (CBC) Concentration of Female Rabbits
}

\author{
Adam Ismail Ahmed ${ }^{1 *}$, Saba Siddig Adam² and Awad Mohammed Babeker ${ }^{1}$ \\ ${ }^{1}$ Department of Food Science and Technology, University of Kordofan, Sudan \\ ${ }^{2}$ Department of Chemistry, University of Kordofan, Sudan
}

*Corresponding author: Adam Ismail Ahmed, Faculty of Natural Resources and Environmental Studies, Department of Food Science and Technology, University of Kordofan, Elobeid, Sudan

To Cite This Article: Adam Ismail A, Saba Siddig A, Awad Mohammed B. The Impacts of Medications Misused for Body Weight Gain on Complete Blood Count (CBC) Concentration of Female Rabbits. Am J Biomed Sci \& Res. 2019 - 1(6). AJBSR.MS.ID.000556.

DOI: 10.34297/AJBSR.2019.01.000556

Received: February 19,2019 | Published: March 15, 2019

\begin{abstract}
The objective of present work was to study the effects of some drugs misused by Sudanese women as body weight gain treatments on complete blood count concentration (CBC) of female rabbits. Sixteen sexually mature female rabbits were procured from local markets of Elnuhod localality, West Kordofan state. A randomized complete block design with three replicates was used; treatments consisted of two drugs i.e. dexamethasone, cyperoheptadine and their combination administered orally with doses of $0.9 \mathrm{mg} / \mathrm{kg}$ of body weight with drugs two times a day for 45 days. Experimental animals were divided into four groups each group with four rabbits. First group as a control, while three groups were injected orally with the above-mentioned treatments, blood parameters were measured every two weeks for 45 days, the variance was analyzed, then means were compared by least significant difference (LSD) test. The results showed that the levels of hemoglobin were ranged between $11.15 \mathrm{~g} / \mathrm{dl}$ and $12.53 \mathrm{~g} /$ dl. Cyperoheptadine and the combination decreased white blood cells with time, lowest value was reported by the combination (3.28). RBC count increased with time, cyperoheptadine recorded 7.23. Packed cell volume was increased with time up to the end of the experiment period. Mean cell volume increased to reach the highest value at 45 days $\left(78.80 \mathrm{~mm}^{3}\right)$ by both cyperoheptadine and the combination followed by dexamethasone $\left(78.43 \mathrm{~mm}^{3}\right)$, which were statistically the same. By the end of the trial, no significant differences were found between the drugs in their effect on the mean cell hemoglobin. Neutrophils decreased with time reached the lowest values of 38.90, 39.53 and $43.05 \%$ for the combination, dexamethasone and cyperoheptadine, respectively. Dexamethasone showed the lowest lymphocyte (33.40\%) as compared with other treatments, as concluded remarks various trends found concerning the relationships between blood parameters influenced by treatments and their normal ranges.
\end{abstract}

Keywords: Administered drugs; Female rabbits; Complete Blood Count (CBC)

\section{Introduction}

The complete blood count (CBC) is one of the most commonly ordered blood tests. To understand this test, it is important to know that blood consists of two major parts: plasma and cellular elements. The plasma is the part of the blood that is liquid which allows the blood to flow easily. The other part of the blood consists of blood cells [1]. The major cells in the blood are white blood cells (WBC), red blood cells (RBC), and platelets. Each of these types of cells carries out specific and important functions. The complete blood count test measures the quantity of all the different types of cells in the blood. It also provides some valuable information on other parameters related to each type of blood cell [1]. A complete blood count (CBC) gives important information about the kinds and numbers of cells in the blood, especially red blood cells, white blood cells and platelets. A CBC can be used to help in symptoms checked, such as weakness, fatigue, or bruising, diagnose conditions, such as anemia, infection, and many other disorders [2-4], the use of body weight gain drugs abused by Sudanese women resulted in decrease in WBCs and increase in RBCs in wistar rats when compared with non-treated once [5], those drugs affect in increasing appetite muscle weakness, impaired wound healing and increased blood sugar levels [6]. According to the important of these blood parameters the present study was designed to investigate the effects of some drugs misused by Sudanese women as body weight gain drugs on complete blood count concentration of female rabbits. 


\section{Material and Methods}

\section{Drugs}

Dexamethasone (Alnagma) and cyperoheptadine (Alpairactin), tablets were obtained from super market in Elobeid, North Kordofan State, Sudan. Each tablet was crashed $(0.9 \mathrm{mg})$ in to powder and then mixed with $1 \mathrm{ml}$ of distilled water and kept as stock drug. Before use the stock suspension was homogenized sonicator and diluted to obtain appropriate doses concentration $(100 \mathrm{ml})$.

\section{Treatments}

Each group was treated with the prepared drugs as follows:

a) First group: left without treatment (control).

b) Second group: administration dexamethasone orally (1.8 $\mathrm{mg} / \mathrm{kg}$ body weight) daily.

c) Third group: administration cyperoheptadine orally (1.8 $\mathrm{mg} / \mathrm{kg}$ body weight) daily.

d) Fourth group: administration the combination dexamethasone and cyperoheptadine orally $(1.8 \mathrm{mg} / \mathrm{kg}$ body weight) daily.

\section{Experimental animals}

Sixteen female rabbits from local markets of Elnuhod weighted 700-2000 grams were divided equally and randomly into four groups (reserved in case of death), Each group was kept in one cage, the animals were provided with composed of green carrot (Caucus carrot) (one of most likely feed of rabbits which available in Sudan) as well as tap water and maintained in air - conditioned quarters (24oC) under standard husbandry conditions with alternate 12 hours light/dark period tell the end of experimental period (45 days).

\section{Blood samples collection}

Blood sample were collected directly from the heart (cardiac puncture) in the first day and then every 15 days till the end of experiment period, blood was collected in plastic tubes with anticoagulant kept in refrigerator pending the analysis during 12 hours period of time, then blood samples were (whole blood) left for blood biochemical parameters (CBC test).

\section{Determination of complete blood count (CBC)}

The complete blood count was determining by using auto hematology analyzer is a quantitative, automated hematology; these techniques were performed according to an automated hematology analyzer (human gambH, max planck - Ring 21, BC3000 Plus Wiesbaden, Germany). The parameters measured were hemoglobin concentration (Hb), packed cell volume (PCV), red blood cells (RBCs), platelets count, white blood Cells (WBCs)differential WBCs counts and erythrocytes indices; mean corpuscular volume (MCV); mean corpuscular hemoglobin (MCH), mean corpuscular hemoglobin concentration (MCHC), platelets (PLT), neutrophils, platelet count, lymphocytes and minimum inhibitory dilution (MID)

\section{Statistical analysis:}

In order to compare the effects of the treatments on the rabbits CBC parameters, all the data obtained were analyzed with ANOVA using a complete randomized design (CRD) with help of computer packaged program SPSS (Statistical Packages for the Social Science) (V.19), mean separation was done using the least significant differences (LSD), as described by Sendecor and Cochran, then the result were tabulated (mean \pm SD) [7].

\section{Results and Discussion}

\section{Effect of administered drugs on the hemoglobin of female rabbits}

At 0 days, 15 days, 30 days and 45 days, there were no significant differences in HB levels between control, dexamethasone, cyperoheptadine and the combination. Referring to comparison within the group at different time points, the control demonstrated no significant differences in level of $\mathrm{HB}$ during the period from 0 - 45 days. In case of dexamethasone, there was no significant difference in level of HB between 0 days and 15, while at 30 days and 45 days showed significant differences as compared to each other and to 0 days and 15 days at 0.05 level of significance. The level of $\mathrm{Hb}$ was increased with time and the highest levels were recorded at $45(12.53 \mathrm{~g} / \mathrm{dl})$ days and 30 days $(11.30 \mathrm{~g} / \mathrm{dl})$. In case of cyperoheptadine, there were no significant differences in levels of HB between 0 days and 15 days, and between 15 days, 30 days and 45 days. It was found that the level of HB increased with time and the highest level was recorded at 45 days $(11.15 \mathrm{~g} / \mathrm{dl})$ which showed significant difference as compared with the level at the beginning of the trial ( $10.33 \mathrm{~g} / \mathrm{dl})$ at 0.05 level of significant. With regards to the combination, there was no significant differences were recorded in HB level between 0 day, 15 days and 30 days, and between 30 days and 45 days. It was found that the level of HB increased with time and the highest value was $11.70 \mathrm{~g} / \mathrm{dl}$ and it was recorded at 45 days, while the lowest value was $10.53 \mathrm{~g} / \mathrm{dl}$ and it was shown at 0 day and the difference between the values was significant at 0.05 level of significance. The results showed that the levels of HB were ranging between $10.15 \mathrm{~g} / \mathrm{dl}$ and $12.53 \mathrm{~g} / \mathrm{dl}$ which indicated that the levels were within the normal range $(9.4-17.4 \mathrm{~g} / \mathrm{dl})$ [8].

\section{Effect of administered drugs on the white blood count (WBC) of female rabbits}

The comparison between the groups at 0 day showed that there was no significant difference in WBC between dexamethasone and the control and between dexamethasone and cyperoheptadine, while their combination recorded the lowest number of 4.7 and the differences between this value and values of other treatments found to be significant at 0.05 level of significance. At 15 days, there was no significant difference was recorded between dexamethasone and the control and between dexamethasone and cyperoheptadine, while their combination recorded the lowest value of WBC number (3.95) and the differences between the combination, the control, dexamethasone and cyperoheptadine were 5.05, 3.78 and 1.83, respectively and these differences are significant at 0.05 level of 
significance. At 30 days, there were significant differences in number of WBC between cyperoheptadine and the control, and between the combination and the control, and between the combination and dexamethasone. The combination recorded the lowest number of WBC (3.95) and the differences between this value and values of other treatments were significant at 0.05 level of significance. At 45 days, dexamethasone, cyperoheptadine and the combination recorded significant differences at 0.05 levels as compared with the control, while there were no significant differences between cyperoheptadine and dexamethasone, and between cyperoheptadine and the combination. The lowest numbers of WBC were recorded by the combination and cyperoheptadine and they were 3.28 and 4.5 , respectively. With regards to comparison within the group, in case of the control, the count of WBC was increased with time and there were no significant differences between counts at different periods of time and the range of WBC count was 8.73 - 9.10 which was within the normal range (5 - 13). For dexamethasone, the count of WBC were decreased with time which agreed with [9] and there were no significant differences between the counts at 15 day, 30 days and 45 days, the lowest count was 6.13 and it was recorded at 45 days, while the highest count was
8.33 which was recorded at 0 time and the difference between two counts was significant at 0.05 level of significance, the range of WBC count during the period of the trial was $8.33-6.13$ which was within the normal limit (5 - 13). In case of cyperoheptadine, the counts of WBC decreased with time and there were no significant differences at 15 days, 30 days and 45 days, the lowest count was 4.5 and it was demonstrated at 45 days, while the highest count was 6.24 and it was recorded at 0 time and the difference between two counts was significant at 0.05 level of significance, the range of WBC count during period 0 - 30 days was $6.25-5.78$ which was within the normal range but at 45 days the count was below the normal limit. Regarding the combination, the count of WBC also decreased with time, the lowest count was recorded at 45 days (3.28) which showed a significant difference when compared with count at 0 time (4.7) at 0.05 level of significance and the range of WBC count was $4.70-3.28$ which was not within the normal range. It can be concluded that the application of dexamethasone, cyperoheptadine and their combination decreased the count of WBC in the blood, and the lowest decreasing rate was demonstrated by dexamethasone, while the highest decreasing rate was shown by their combination (Table 1 \& 2).

Table 1: Effect of administered drugs on the Hemoglobin (HB) of female rabbits.

\begin{tabular}{|c|c|c|c|c|}
\hline \multirow{2}{*}{ Treatments } & \multicolumn{4}{|c|}{ Periods (days) } \\
\hline & Zero time & 15 & 30 & 45 \\
\hline Control & $(10.75) \mathrm{Aa} \pm 0.33$ & $(10.70) \mathrm{Aa} \pm 0.61$ & (11.43) Aa \pm 0.65 & $(11.98) \mathrm{Aa} \pm 1.11$ \\
\hline Dexamethasone & $(10.15)$ Ac \pm 0.49 & $(10.45) \mathrm{Ac} \pm 0.42$ & $(11.30) \mathrm{Ab} \pm 0.43$ & $(12.53) \mathrm{Aa} \pm 0.72$ \\
\hline Cyperoheptadine & $(10.33) \mathrm{Ab} \pm 0.24$ & $(10.63) \mathrm{Aab} \pm 0.30$ & $(10.88) \mathrm{Aa} \pm 0.31$ & $(11.15) \mathrm{Aa} \pm 0.51$ \\
\hline Dexa and Cyper & $(10.53) \mathrm{Ab} \pm 0.43$ & $(10.70) \mathrm{Ab} \pm 0.43$ & $(10.50) \mathrm{Aab} \pm 0.59$ & $(11.70) \mathrm{Aa} \pm 0.80$ \\
\hline
\end{tabular}

Table 2: Effect of administered drugs on the white blood count (WBC) of female rabbits.

\begin{tabular}{|c|c|c|c|c|}
\hline \multirow{2}{*}{ Treatments } & \multicolumn{4}{|c|}{ Periods (days) } \\
\hline & Zero time & 15 & 30 & 45 \\
\hline Control & $(8.73) \mathrm{Aa} \pm 1.21$ & $(9.00) \mathrm{Aa} \pm 1.78$ & $(9.00) \mathrm{Aa} \pm 1.76$ & $(9.10) \mathrm{Aa} \pm 0.98$ \\
\hline Dexamethasone & (8.33) $\mathrm{ABa} \pm 1.20$ & (7.73) $\mathrm{ABab} \pm 1.26$ & $(7.73) \mathrm{ABab} \pm 1.41$ & (6.13) $\mathrm{Bb} \pm 1.48$ \\
\hline Cyperoheptadine & (6.25) BCa \pm 0.98 & (5.78) BCab \pm 0.99 & (5.78) BCab \pm 1.11 & $(4.50) \mathrm{BCb} \pm 0.74)$ \\
\hline Dexa and Cyper & $(4.70) \mathrm{Ca} \pm 0.32$ & (3.95) $\mathrm{Cb} \pm 0.06$ & $(3.95) \mathrm{Cb} \pm 0.17)$ & $(3.28) \mathrm{Cc} \pm 0.29$ \\
\hline
\end{tabular}

Each value is an average of three replicates.

Each value is average \pm standard deviation.

Values in column share the same superscript capital letters show no significant difference between groups at 0.05 levels.

Values in Rows share the same superscript small letters show no significant difference within groups at 0.05 levels.

\section{Effect of administered drugs on the Red Blood cells (RBC) of female rabbits}

In case of comparison between the treatments it was found that there were no significant differences between treatments at 0 days. After 15 days, the combination of dexamethasone cyperoheptadine recorded the lowest value of $\mathrm{RBC}\left(4.90 \mathrm{~mm}^{3}\right)$ which showed significant difference as compared with control and other two drugs at 0.05 level of significance, but the value was within the normal range $\left(3.8-7.9 \mathrm{~mm}^{3}\right)$. After 30 days, the values of $\mathrm{RBC}$ recorded by dexamethasone, cyperoheptadine and their combination were higher than the value recorded by the control and the difference between each drug and the control was significant at 0.05 level but no significant differences were found between the drugs, the highest value of RBC was $7.58 \mathrm{~mm}^{3}$ and it was reported by the combination, while the lowest value was $5.08 \mathrm{~mm}^{3}$ and it was recorded by the control but all values of RBC were within the normal range. After 45 days, the highest values of RBC were $8.83 \mathrm{~mm}^{3}$ and $8.08 \mathrm{~mm}^{3}$ and they were reported by the combination and dexamethasone, respectively the two values were above the upper limit of normal range of RBC and they showed significant differences as compared 
with the control $\left(5.33 \mathrm{~mm}^{3}\right)$ and with cyperoheptadine $\left(7.23 \mathrm{~mm}^{3}\right)$, furthermore, cyperoheptadine recorded a significant difference as compared with the control at 0.05 level of significance, it was found that the values reported by the control and cyperoheptadine were within the normal range of RBC. In case of comparison within the treatment at different points of time, the control showed no significant differences in RBC throughout the period from 0 to 45 days. Considering dexamethasone, it was found that volume of $\mathrm{RBC}$ increased with time and the highest value was $8.08 \mathrm{~mm}^{3}$ and it was recorded at 45 days and found to be more than the upper limit of normal range but there was no significant difference in RBC between 15 days and 30 days. In case of cyperoheptadine also it was noticed that the values of RBC increased with time and the highest value was $7.23 \mathrm{~mm}^{3}$ and it was recorded at 45 days, but it was found to be within the normal range. Effect of the combination was increased with time at 30 days and 45 days and the highest value was $8.83 \mathrm{~mm}^{3}$ at 45 days and it was above the upper limit of normal range. It can be concluded that at the end of trial period, the highest RBC counts in descending sequence were recorded by the combination, dexamethasone and cyperoheptadine.

\section{Effect administered drugs on the plate count $/ \mathrm{mm}^{3}$ of female rabbits}

There were no significant differences between treatments at 0 time, 30 days and 45 days. At 15 days there were no significant differences in plate counts between dexamethasone, cyperoheptadine and the control, while the combination recorded the lowest count of plates and showed significant $(\mathrm{p} \leq 0.05)$ difference as compared with control, but showed no significant differences as compared with dexamethasone and cyperoheptadine. A plates count recorded by all treatment was found to be within the normal range $\left(200-650 \mathrm{~mm}^{3}\right)$. With regards to comparison within the group at different points of time, the control, dexamethasone, cyperoheptadine and their combination showed no significant differences throughout the trial period, at 15 days, 30 and 45 days, cyperoheptadine and the combination demonstrated little increments in plates count while there were small reductions were noticed in case of dexamethasone at 30 days and 45 days. Generally, it can be concluded that the effect of different drugs on plate count is ignorable and the change in the count due to drugs application is fluctuated (Table $3 \& 4$ ).

Table 3: Effect administered drugs on the Red Blood cells (RBC) of female rabbits.

\begin{tabular}{|c|c|c|c|c|}
\hline \multirow{2}{*}{ Treatments } & \multicolumn{4}{|c|}{ Periods (days) } \\
\cline { 2 - 5 } & Zero time & $\mathbf{1 5}$ & $\mathbf{3 0}$ & $\mathbf{4 5}$ \\
\hline Control & $(5.38) \mathrm{Aa} \pm 0.67$ & $(6.55) \mathrm{Aa} \pm 0.71$ & $(5.08) \mathrm{Ba} \pm 0.52$ & $(5.33) \mathrm{Ca} \pm 0.31$ \\
\hline Dexamethasone & $(5.23) \mathrm{Ac} \pm 0.34$ & $(6.25) \mathrm{Ab} \pm 0.57$ & $(7.00) \mathrm{Ab} \pm 0.65$ & $(8.08) \mathrm{ABa} \pm 0.61$ \\
\hline Cyperoheptadine & $(5.08) \mathrm{Ac} \pm 0.25$ & $(5.95) \mathrm{ABbc} \pm 0.25$ & $(6.75) \mathrm{Aab} \pm 0.98$ & $(7.23) \mathrm{Ba} \pm 1.13$ \\
\hline Dexa and Cyper & $(5.05) \mathrm{Ad} \pm 0.42$ & $(4.90) \mathrm{Bc} \pm 0.44$ & $(7.58) \mathrm{Ab} \pm 0.74$ & $(8.83) \mathrm{Aa} \pm 0.57$ \\
\hline
\end{tabular}

Table 4: Effect administered drugs on the plate count of female rabbits

\begin{tabular}{|c|c|c|c|c|}
\hline \multirow{2}{*}{ Treatments } & \multicolumn{4}{|c|}{ Periods (days) } \\
\hline & Zero time & 15 & 30 & 45 \\
\hline Control & $(427.50) \mathrm{Aa} \pm 22.16$ & 426.75) Аa \pm 18.99$)$ & $(428.25)$ Aa \pm 19.41 & $(428.75) \mathrm{Aa} \pm 19.57$ \\
\hline Dexamethasone & $(373.00) \mathrm{Aa} \pm 107.10$ & (394.75) $\mathrm{ABa} \pm 83.78$ & $(358.75) \mathrm{Aa} \pm 99.98$ & $(352.50) \mathrm{Aa} \pm 52.37$ \\
\hline Cyperoheptadine & $(343.25) \mathrm{Aa} \pm 98.49$ & $(274.00) \mathrm{ABa} \pm 99.08$ & (385.25) Aa \pm 93.15 & $(412.50) \mathrm{Aa} \pm 100.04$ \\
\hline Dexa and Cyper & $(262.75) \mathrm{Aa} \pm 93.59$ & $(249.50) \mathrm{Ba} \pm 106.12$ & (306.25) Aa \pm 100.94 & (376.75) Aa \pm 93.16 \\
\hline \multicolumn{5}{|c|}{ Each value is an average of three replicates. } \\
\hline \multicolumn{5}{|c|}{ Each value is average \pm standard deviation } \\
\hline \multicolumn{5}{|c|}{ Values in column share the same superscript capital letters show no significant difference between groups at 0.05 levels. } \\
\hline \multicolumn{5}{|c|}{ Values in Rows share the same superscript small letters show no significant difference within groups at 0.05 levels. } \\
\hline
\end{tabular}

\section{Effect of administered drugs on the cell volume (CV) of female rabbits}

There were no significant differences between treatments at 0 time, 15 days and 30 days in their effect on packed cell volume. At 45 days there was no significant differences in cell volume between dexamethasone, cyperoheptadine and the control and no significant difference between the combination and dexamethasone but the combination recorded the highest value of packed cell volume (49 $\%$ ) which showed significant differences as compared with the control and cyperoheptadine at 0.05 level but showed no significant differences as compared with dexamethasone and cyperoheptadine. With regards to comparison within the group at different points of time, the control showed no significant differences in packed cell volume were recorded in case of the control from 0 time to 45 days. Dexamethasone at 45 days showed significant differences as compared with 0 time, 15 days and 30 days. Cyperoheptadine at 45 days recorded significant differences as compared with 0 time and 15 days. In case of the combination at 45 days, there were sign significant differences were recorded when compared with 0 time and 15 days. The range of packed cell volume was $35.18 \%-49.63$ so, it is within the normal range (33 \% - $50 \%)$. 
It can be concluded that the packed cell volume increased with time and at end of experiment period, the combination recorded the highest packed cell volume followed by dexamethasone and finally cyperoheptadine.

\section{Effect of administered drugs on mean cell volume (MCV) of female rabbits}

There were no significant differences between treatments at 0 time, 15 days and 45 days in their effect on mean cell volume. At 30 days there were no significant differences in men cell volume between dexamethasone, cyperoheptadine and their combination, but these drugs showed significant differences at 0.05 levels as compared with control. With respect to comparison within the group at different points of time, the control, no significant differences in men cell volume were recorded in case of the control from 0 time to 45 days. Dexamethasone at 45 days showed significant differences as compared with 0 times but showed no significant differences when compared with 15 days and 30 days. Cyperoheptadine at 45 days recorded significant differences as compared with 0 time and 15 days. In case of the combination at 45 days, there were sign significant $(\mathrm{p} \leq 0.05)$ differences were recorded when compared with 0 time and 15 days. It was found that the men cell volume when the drugs were applied increased with time and reached its highest value at 45 days $\left(78.80 \mathrm{~mm}^{3}\right)$ and that value was reported by both cyperoheptadine and the combination followed by dexamethasone $\left(78.43 \mathrm{~mm}^{3}\right)$. During the time period $30-45$ days, the range of men cell volume due to drugs effect was $75.35-78.80 \mathrm{~mm}^{3}$ which was out the normal range $\left(50-75 \mathrm{~mm}^{3}\right)$ [8] (Table 5 \& 6).

Table 5: Effect of administered drugs on packed cell volume $(\mathrm{PCV}) / \mathrm{mm}^{3}$ of female Rabbits.

\begin{tabular}{|c|c|c|c|c|}
\hline \multirow{2}{*}{ Treatments } & \multicolumn{4}{|c|}{ Periods (days) } \\
\cline { 2 - 5 } & Zero time & $\mathbf{1 5}$ & $\mathbf{3 0}$ & $\mathbf{4 5}$ \\
\hline Control & $(40.10) \mathrm{Aa} \pm 5.25$ & $(39.95) \mathrm{Aa} \pm 5.76$ & $(40.05) \mathrm{Aa} \pm 5.41$ & $(40.13) \mathrm{Ba} \pm 5.10$ \\
\hline Dexamethasone & $(35.18) \mathrm{Ad} \pm 1.71$ & $(38.13) \mathrm{Ac} \pm 1.36$ & $(40.65) \mathrm{Ab} \pm 1.11$ & $(44.80) \mathrm{ABa} \pm 1.07$ \\
\hline Cyperoheptadine & $(37.38) \mathrm{Abc} \pm 0.92$ & $(37.38) \mathrm{Abc} \pm 1.02$ & $(38.78) \mathrm{Aab} \pm 1.27$ & $(40.30) \mathrm{Ba} \pm 1.61$ \\
\hline Dexa and Cyper & $(36.30) \mathrm{Ac} \pm 2.22$ & $(40.93) \mathrm{Abc} \pm 3.83$ & $(45.28) \mathrm{Aab} \pm 4.45$ & $(49.63) \mathrm{Aa} \pm 4.88$ \\
\hline
\end{tabular}

Table 6: Effect of administered drugs on Mean cell volume (MCV) of female Rabbits.

\begin{tabular}{|c|c|c|c|c|}
\hline \multirow{2}{*}{ Treatments } & \multicolumn{5}{|c|}{ Periods (days) } \\
\cline { 2 - 5 } & Zero time & $\mathbf{1 5}$ & $\mathbf{3 0}$ & $(64.30) \mathrm{Aa} \pm 9.14$ \\
\hline Control & $(62.55) \mathrm{Aa} \pm 5.23$ & $(64.45) \mathrm{Aa} \pm 8.12$ & $(64.90) \mathrm{Ba} \pm 3.94$ & $(78.43) \mathrm{Aa} \pm 6.38$ \\
\hline Dexamethasone & $(69.05) \mathrm{Ab} \pm 1.67$ & $(71.90) \mathrm{Aab} \pm 3.21$ & $(75.38) \mathrm{Aab} \pm 4.80$ & $(78.80) \mathrm{Aa} \pm 5.98$ \\
\hline Cyperoheptadine & $(66.20) \mathrm{Ac} \pm 4.24$ & $(71.10) \mathrm{Abc} \pm 3.16$ & $(75.35) \mathrm{Aab} \pm 5.14$ & $(78.80) \mathrm{Aa} \pm 5.98$ \\
\hline Dexa and Cyper & $(65.95) \mathrm{Ac} \pm 4.34$ & $(71.10) \mathrm{Abc} \pm 3.16$ & $(75.35) \mathrm{Aab} \pm 5.14$ & \\
\hline
\end{tabular}

\section{Effect of administered drugs on mean cell hemoglobin (MCH) in pg/cell of female rabbits}

There were no significant differences between treatments at 0 time, 15 days, 30 days and 45 days in their effect on men cell hemoglobin. With respect to comparison within the group at different points of time, the control, no significant differences in men cell hemoglobin were recorded in case of the control from 0 time to 45 days. Dexamethasone at 45 days showed significant ( $p \leq 0.05$ ) differences as compared with 0 times but showed no significant $(\mathrm{p} \leq 0.05)$ differences when compared with 15 days and 30 days. Cyperoheptadine recorded no significant $(p \leq 0.05)$ differences between the different points of time. In case of the combination, there were no significant $(p \leq 0.05)$ differences in values of men cell hemoglobin between 15 days, 30 days and 45 days and also no significant differences between 0 time, 15 days and 30 days, but there was significant difference between 0 time and 45 days there was significant $(\mathrm{p} \leq 0.05)$ difference. It was found that the men cell hemoglobin value increased with time and the highest values was recorded at 45 days with magnitudes of $26.28 \mathrm{pg} /$ cell, $23.78 \mathrm{pg} /$ cell and $22.50 \mathrm{pg}$ / cell and they were recorded by dexamethasone, the combination of and cyperoheptadine respectively and only dexamethasone recorded a value that considered above the upper limit of the normal range of men cell hemoglobin which is $24 \mathrm{pg} /$ cell. It can be concluded that all drugs generally increase the men cell hemoglobin even if with small portion.

\section{Effect of administered drugs on mean cell hemoglobin concentration (MCHC) \% of female rabbits}

At 0-time, dexamethasone, cyperoheptadine and their combination recorded significant differences as compared with the control and cyperoheptadine reported significant $(p \leq 0.05)$ differences when contrasted to dexamethasone and the combination of significance, while the difference between dexamethasone and the combination was not significant. At 15 days dexamethasone and the combination recorded significant differences as contrasted with the control and cyperoheptadine, but they showed no significant difference when compared with each other. The difference between cyperoheptadine and the control was not significant. At 30 days, dexamethasone and the combination recorded significant $(p \leq 0.05)$ differences as compared with the control and cyperoheptadine, while there was no significant difference was reported between cyperoheptadine and the control. At 45 days, dexamethasone and cyperoheptadine indicated significant differences compared to the control at 0.05 levels, but they demonstrated no significant differences as contrasted to the combination of, moreover the 
combination reported no significant ( $\mathrm{p} \leq 0.05)$ difference as weighted against the control. In case of the comparison within group at different points of time, the control and dexamethasone reported no significant differences between all points from 0 times up to 45 days. Cyperoheptadine showed no significant difference between 30 days and 45 days but it reported significant difference at 0.05 levels between 45 days compared with 0 time and 15 days, furthermore, there was significant difference at 0.05 levels between 30 days and 0 time. The combination showed significant $(\mathrm{p} \leq 0.05)$ differences between 30 days and 0 time and between 45 days and 0 time, but there were no significant $(p \leq 0.05)$ differences were found between 15 days and 30 days, and between 0 time and 15 days. The results demonstrated that MCHC in case of dexamethasone increased with time and reached its highest value of 34.45 at end of the trial period ( 45 days), in case of cyperoheptadine MCHC level decreased with time and reached its lowest value of 37.03 at end of the trial, while in case of the combination MCHC increased with time and reached its highest value of 43.85 at end of the trial. The level of MCHC in case of the control found to be fluctuating at different points of time throughout the trial period. It can be concluded that dexamethasone and the combination increased the level of MCHC, while cyperoheptadine decreased it (Table $7 \& 8$ ).

Table 7: Effect of administered drugs o Men cell Hemoglobin (MCH) of female rabbits.

\begin{tabular}{|c|c|c|c|c|}
\hline \multirow{2}{*}{ Treatments } & \multicolumn{4}{|c|}{ Periods (days) } \\
\cline { 2 - 5 } & Zero time & $\mathbf{1 5}$ & $\mathbf{3 0}$ & $\mathbf{4 5}$ \\
\hline Control & $(19.35) \mathrm{Aa} \pm 0.75$ & $(21.00) \mathrm{Aa} \pm 2.84$ & $(19.23) \mathrm{Aa} \pm 0.67$ & $(20.65) \mathrm{Aa} \pm 2.99$ \\
\hline Dexamethasone & $(19.90) \mathrm{Ab} \pm 1.04$ & $(22.10) \mathrm{Aab} \pm 19.50$ & $(23.70) \mathrm{Aab} \pm 3.46$ & $(26.28) \mathrm{Aa} \pm 4.14$ \\
\hline Cyperoheptadine & $(19.95) \mathrm{Aa} \pm 1.25$ & $(20.325) \mathrm{Aa} \pm 1.3817$ & $(21.26) \mathrm{Aa} \pm 1.55$ & $(22.50) \mathrm{Aa} \pm 2.55$ \\
\hline Dexa and Cyper & $(19.58) \mathrm{Ab} \pm 0.51$ & $(20.08) \mathrm{Aab} \pm 0.42$ & $(22.00) \mathrm{Aab} \pm 2.57$ & $(23.78) \mathrm{Aa} \pm 4.40$ \\
\hline
\end{tabular}

Table 8: Effect of administered drugs o men cell hemoglobin concentration (MCHC) of female rabbits

\begin{tabular}{|c|c|c|c|c|}
\hline \multirow{2}{*}{ Treatments } & \multicolumn{4}{|c|}{ Periods (days) } \\
\hline & Zero time & 15 & 30 & 45 \\
\hline Control & $(50.23) \mathrm{Ba} \pm 5.21$ & (54.70) Aa \pm 12.50 & $(51.85) \mathrm{Aa} \pm 6.51$ & $(60.25) \mathrm{Aa} \pm 11.8$ \\
\hline Dexamethasone & $(26.75) \mathrm{Ca} \pm 4.50$ & $(26.90) \mathrm{Ba} \pm 4.10$ & (31.23) Ba \pm 6.21 & $(34.45) \mathrm{Ba} \pm 8.53$ \\
\hline Cyperoheptadine & $(63.75) \mathrm{Aa} \pm 4.57$ & $(53.00) \mathrm{Ab} \pm 5.72$ & $(45.175) \mathrm{Abc} \pm 6.21$ & $(37.03) \mathrm{Bc} \pm 8.53$ \\
\hline Dexa and Cyper & $(29.16) \mathrm{Cc} \pm 0.66$ & (34.43) Bbc \pm 3.58 & (38.68) $\mathrm{ABab} \pm 8.78$ & (43.85) $\mathrm{ABa} \pm 8.78$ \\
\hline \multicolumn{5}{|c|}{ Each value is an average of three replicates. } \\
\hline \multicolumn{5}{|c|}{ Each value is average \pm standard deviation } \\
\hline \multicolumn{5}{|c|}{ Values in column share the same superscript capital letters show no significant difference between groups at 0.05 levels. } \\
\hline \multicolumn{5}{|c|}{ Values in Rows share the same superscript small letters show no significant difference within groups at 0.05 levels. } \\
\hline
\end{tabular}

\section{Effect of administered drugs on neutrophils percentage of female rabbits}

There were no significant differences between treatments at 0 time, 15 days, 30 days and 45 days in their effect on Neutrophils percentage. With respect to comparison within the group at different points of time, no significant differences in Neutrophils percentage were recorded in case of the control from 0 times to 45 days. Dexamethasone at 45 days showed significant differences at 0.05 levels as compared with 0 time and 15 days but showed no significant differences when compared with 30 days and 30 days. Cyperoheptadine recorded no significant differences between 15 days, 30 days and 45 days but at 30 days and 45 days there were significant differences when compared with 0 time. In case of the combination, there were significant $(\mathrm{p} \leq 0.05)$ differences in values neutrophils percentage between 45 days and 0 time, 15 days and 35 days. It was found that neutrophils percentage decreased with time which agreed with [9], in case of dexamethasone, and the lowest values were recorded at 45 days and they are $38.90 \%$, $39.53 \%$ and $43.05 \%$ which are demonstrated by the combination, dexamethasone and cyperoheptadine, respectively, while the highest value was $53.5 \%$ which reported by the control. At 0 times, the highest percentage of neutrophils was $61.50 \%$ and it was shown by dexamethasone. For all treatment, the range of neutrophils percentage was within the normal range of $34-70$ (Jones, 1975).

\section{Effect of administered drugs on lymphocyte\% of female rabbits}

At 0 time and 15 days there were no significant $(\mathrm{p} \leq 0.05)$ differences between dexamethasone, cyperoheptadine and the combination in their effect on lymphocyte percentage, while there were significant $(p \leq 0.05)$ differences between these drugs and the control. At 30 days, no significant $(p \leq 0.05)$ differences between dexamethasone, cyperoheptadine and their combination, but dexamethasone, cyperoheptadine drugs showed significant $(\mathrm{p} \leq$ 0.05 ) differences compared with the control, while the combination recorded no significant $(\mathrm{p} \leq 0.05)$ different as compared with the control. At 45 days, there were no significant $(\mathrm{p} \leq 0.05)$ differences between dexamethasone, cyperoheptadine and the combination of in their effect on lymphocyte percentage, but only dexamethasone drug showed significant ( $p \leq 0.05)$ difference as compared with the control. Considering the comparison within the group, the control and dexamethasone revealed no significant $(\mathrm{p} \leq 0.05)$ difference 
throughout the experimental period. In case of cyperoheptadine, the highest lymphocyte percentages were $42.30 \%$ and $39.55 \%$ in 42 days and 30days, respectively. Regarding the combination, $49.93 \%, 47.23 \%$ and $41.98 \%$ and they were recorded at 42 days, 30 days and 15 days respectively. In case of cyperoheptadine and the combination, lymphocyte percentage found to be increased with time. At 42 days, dexamethasone recorded $33.40 \%$ lymphocyte percentage which is below the lower limit of normal range (43$80 \%$ ) which agreed with [9], cyperoheptadine recorded $42.3 \%$ which is around the lower limit of normal range, while the control and the combination showed $58.75 \%$ and $49.93 \%$, respectively and these values were found to be within the normal range. It can be concluded that dexamethasone caused significant reduction in lymphocyte percentage as compared with the control.

\section{Effect of administered drugs on minimum inhibitor dilution (Mid) of female rabbits}

There were no significant differences between treatments at 0 time, 15 days, 30 days and 45 days in their effect on MID percentage. With respect to comparison within the group at different points of time, no significant differences in MID percentage were recorded in case of the control from 15 times to 45 days, but there was significant difference was recorded between 0 time and 45 days at 0.05 level. Dexamethasone, cyperoheptadine and their combination recorded no significant differences between 0 times up to 45 days. It was found that MID percentage increased with very small ratio. For all treatment, the range of MID percentage was within the normal range (0 - $2 \%$ ) (Table 9 - 11).

Table 9: Effect of administered drugs on Neutrophils of female rabbits

\begin{tabular}{|c|c|c|c|c|}
\hline \multirow{2}{*}{ Treatments } & \multicolumn{5}{|c|}{ Periods (days) } & $\mathbf{3 0}$ & $\mathbf{4 5}$ \\
\cline { 2 - 5 } & Zero time & $\mathbf{1 5}$ & $(50.75) \mathrm{Aa} \pm 5.19$ & $(53.50) \mathrm{Aa} \pm 7.94$ \\
\hline Control & $(55.00) \mathrm{Aa} \pm 10.39$ & $(53.500) \mathrm{Aa} \pm 8.54$ & $(45.18) \mathrm{Abc} \pm 6.21$ & $(39.53) \mathrm{Ac} \pm 9.88$ \\
\hline Dexamethasone & $(61.50) \mathrm{Aa} \pm 5.80$ & $(53.00) \mathrm{Aab} \pm 5.73$ & $(46.55) \mathrm{Aab} \pm 7.86$ & $(43.05) \mathrm{Ab} \pm 8.10$ \\
\hline Cyperoheptadine & $(55.35) \mathrm{Aa} \pm 4.91$ & $(52.70) \mathrm{Aab} \pm 8.63$ & $(45.15) \mathrm{Ab} \pm 4.38$ & $(38.90) \mathrm{Ac} \pm 4.408$ \\
\hline Dexa and Cyper & $(55.50) \mathrm{Aa} \pm 3.50$ & $(50.95) \mathrm{Aab} \pm 3.07$ & &
\end{tabular}

Table 10: Effect of administered drugs on Lymphocyte of female rabbits.

\begin{tabular}{|c|c|c|c|c|}
\hline \multirow{2}{*}{ Treatments } & \multicolumn{4}{|c|}{ Periods (days) } \\
\cline { 2 - 5 } & Zero time & $\mathbf{1 5}$ & $\mathbf{3 0}$ & $\mathbf{4 5}$ \\
\hline Control & $(56.15) \mathrm{Aa} \pm 12.07$ & $(61.85) \mathrm{Aa} \pm 16.8$ & $(58.55) \mathrm{Aa} \pm 15.24$ & $(58.75) \mathrm{Aa} \pm 14.43$ \\
\hline Dexamethasone & $(28.50) \mathrm{Ba} \pm 3.11$ & $(30.18) \mathrm{Ba} \pm 15.24$ & $(30.98) \mathrm{Ba} \pm 3.58$ & $(33.40) \mathrm{Ba} \pm 5.12$ \\
\hline Cyperoheptadine & $(35.78) \mathrm{Bb} \pm 3.64$ & $(37.57) \mathrm{Bb} \pm 3.13$ & $(39.55) \mathrm{Bab} \pm 2.14$ & $(42.30) \mathrm{ABa} \pm 2.40$ \\
\hline Dexa and Cyper & $(38.40) \mathrm{Bb} \pm 4.25$ & $(41.98) \mathrm{Bab} \pm 5.26$ & $(47.23) \mathrm{ABab} \pm 7.82$ & $(49.93) \mathrm{ABa} \pm 9.03$ \\
\hline
\end{tabular}

Table 11: Effect of administered drugs on Minimum Inhibitor Dilution (Mid) of female rabbits:

\begin{tabular}{|c|c|c|c|c|}
\hline \multirow{2}{*}{ Treatments } & \multicolumn{4}{|c|}{ Periods (days) } \\
\cline { 2 - 5 } & Zero time & $\mathbf{1 5}$ & $\mathbf{3 0}$ & $\mathbf{4 5}$ \\
\hline Control & $(0.68) \mathrm{Ab} \pm 0.05$ & $(0.75) \mathrm{Aab} \pm 0.10$ & $(0.85) \mathrm{Aab} \pm 0.10$ & $(0.95) \mathrm{Aa} \pm 0.26$ \\
\hline Dexamathsone & $(0.78) \mathrm{Aa} \pm 0.15$ & $(1.00) \mathrm{Aa} \pm 0.37$ & $(1.13) \mathrm{Aa} \pm 0.52$ & $(0.05) \mathrm{Aa} \pm 0.33$ \\
\hline Cyperoheptadine & $(0.73) \mathrm{Aa} \pm 0.13$ & $(0.68) \mathrm{Aa} \pm 0.0957$ & $(0.78) \mathrm{Aa} \pm 0.13$ & $(0.83) \mathrm{Aa} \pm 0.22$ \\
\hline Dexa and Cyper & $(0.63) \mathrm{Aa} \pm 0.0957$ & $(0.65) \mathrm{Aa} \pm 0.06$ & $(0.70) \mathrm{Aa} \pm 0.14$ & \\
\hline
\end{tabular}

\section{Conclusion and Recommendation}

Application of dexamethasone, cyperoheptadine and their combination decreased the count of white blood cells and increased Red Blood cells level in the blood according to the indicated sequence. Cyperoheptadine and the combination demonstrated little increments in plates count, while small reductions were noticed in case of dexamethasone. The combination recorded the highest packed cell volume followed by dexamethasone and finally cyperoheptadine. Mean cell volume increased in sequence by cyperoheptadine, the combination, and all drugs increase the mean cell hemoglobin by small portions. Dexamethasone and the combination increase the level of mean cell hemoglobin concentration, while cyperoheptadine decreases level of mean cell hemoglobin concentration. Neutrophils percentage decreases with time for all drugs, the combination, dexamethasone and cyperoheptadine, while dexamethasone causes significant reduction in lymphocyte percentages.

\section{Acknowledgments}

The authors appreciated the help given by the staff of central veterinary laboratory, Elobeid, Department of chemistry faculty of education; the help given by the dean faculty of natural resources and environmental studies is also appreciated.

\section{Conflicts of Interest}

The authors declared that no conflicts of interest for this article. 


\section{Ethical Permission}

Ethical permission was taken from the wildlife authority department action no (52/5/A/6M).

\section{References}

1. Fischbach FT, Dunning MB III (2009) Manual of Laboratory and Diagnostic Tests. ( $8^{\text {th }}$ edn.) Lippincott Williams and Wilkins, Philadelphia.

2. Chernecky CC, Berger BJ (2008) Laboratory Tests and Diagnostic Procedures ( $5^{\text {th }}$ edn) Saunders, St Louis, USA.

3. Kaneko JJ (1989) Clinical biochemistry of domestic animals. Academic Press, New-York.

4. Kerr M (1989) Veterinary Laboratory Medicine. Clinical Biochemistry and Hematology, Blackwell Scientific Publications.

5. Amar MI, Adam Shama IY, Enaia AA, Hind AEO, Higer AM (2013) Effects of various levels of oral doses dexamethasone (Alnagma) abused as cosmetic by Sudanese women on Wistar rats. J Med Sci 13(6): 432-438.

6. Pagana KD, Pagana TJ (2010) Mosby's Manual of Diagnostic and Laboratory Tests. ( $4^{\text {th }}$ edn.) St. Louis: Mosby Elsevier.
7. Sendecor GW, Cochran WC (1989) Statistical Method (8 ${ }^{\text {th }}$ edn). Iowa State Univiersity press, Ames, Iowa, Murray RK, DK Granner, PA Mayes, et al. (2006) Harpers I11 lustrated Biochemistry ( $27^{\text {th }}$ edn), MC GrawHill, New York, pp. 489-504.

8. Jones RT (1975) Normal values for some biochemical constituents in rabbits. Lab Anim 9(2): 143-147.

9. Kaoru T, Kazuhiko I, Shoko Aritoshi, Shunta Akimoto, Takamasa Ban, et al. (2010) Acute and Subacute Effects of Dexamethasone on the Number of White Blood Cells in Rats. Journal of Health Science 56(2): 215-220.

10. American Association for Clinical Chemistry (2010) Retrieved on May 24, 2012, from http: // lab test online. Org/ understanding / analytes/ prolactin/tab/test.

11. Siddigui E, GIQ azi (2012) Role of Dexamethasone in Meningitis. In: Meningitis, Wireko- Brobby G (Ed) intech, USA.

12.Welsh AL, M Ede (2013) Studies of Cyperoheptadine combined with Dexsamethsone. J Clin pharmacol 2: 223-231. 